Supporting Information

\title{
Distribution and Emission Estimation of Short- and Medium-Chain Chlorinated Paraffins in Chinese Products through Detection-Based Mass Balancing
}

Chengkang Chen ${ }^{1}$, Anna Chen ${ }^{1}, \mathrm{Li} \mathrm{Li}^{2}$, Wangyuan Peng ${ }^{1}$, Roland Weber ${ }^{3}$, Jianguo Liu ${ }^{1 *}$

${ }^{1}$ State Key Joint Laboratory for Environmental Simulation and Pollution Control, College of Environmental Sciences and Engineering, Peking University, Beijing 100871, China.

${ }^{2}$ School of Community Health Sciences, University of Nevada, Reno, Reno, Nevada, 89557, USA ${ }^{3}$ POPs Environmental Consulting, Lindenfirststr 23, Schwäbisch Gmünd 73527, Germany

*Corresponding author: (J. L.) jgliu@ @ku.edu.cn

The supporting Information contains 35 pages, 18 tables and 5 figures. 


\section{Materials and Methods}

\subsection{Industry survey}

Figure S1. The spatial distribution of CP production capacity (the left panel) and use (the right panel) in China according to our industry survey and the provincial distribution of sample collection (marked as asterisks).

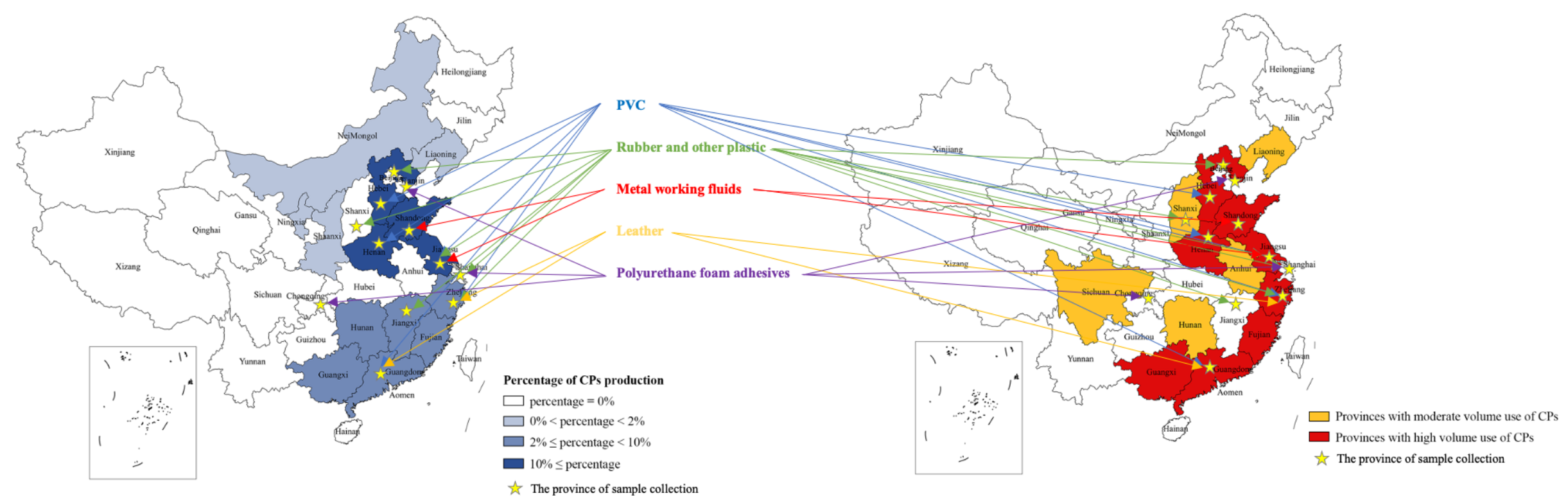




\subsection{Sample extraction and instrumental analysis for SCCPs and MCCPs in products}

\subsubsection{Instruments and reagents}

The instruments and part of the reagents we used for analyzing SCCPs and MCCPs in products are referenced to ISO 18219: 2015. MCCPs standard reagents in the experiment were based on commercial standards. The specific detection operations were performed by SGS Guangzhou.

Instruments: Analytical balance; Sealable vessel with lid (20 ml, suitable for extraction with n-hexane); Ultrasonic bath (temperature controlled; (EMMI60HC, Emag, Germany)); Pipette; Volumetric flask; Solid phase extraction (SPE) system (Soaring Technology, China), with vacuum device and normal phase SPE cartridges; PTFE membrane filter; Gas chromatograph and mass selective detector with chemical ionization (GC-ECNI-MS, Focus ISQ, ThermoFisher, America).

Reagents: $\mathrm{n}$-hexane; Dichloromethane; Internal standard solution $\left(1,1,1,3,10,11\right.$-hexachloroundecane, ${ }^{13} \mathrm{C}_{10}$-labeled, $\left.1000 \mu \mathrm{g} / \mathrm{ml}\right)$; Standard solutions SCCPs, $\mathrm{C}_{10}-\mathrm{C}_{13}$ with different chlorine content, each $100 \mu \mathrm{g} / \mathrm{ml}$ : SCCPs $\mathrm{C}_{10}-\mathrm{C}_{13} 55.5 \% \mathrm{Cl}$ (technical grade), $\mathrm{SCCPs}_{10}-\mathrm{C}_{13} 59 \% \mathrm{Cl}$

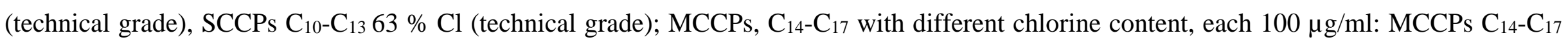

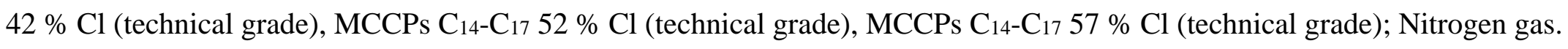

\subsubsection{Sample extraction}

All samples were washed by deionized water to remove the dust on the surface and also remove glue residues by mechanical method, after which the samples were cut into small pieces and air dried in a fume hood. $0.5 \mathrm{~g} \pm 0.001 \mathrm{~g}$ test sample was weighed with the analytical balance into the sealable vessel. $9.9 \mathrm{ml}$-hexane and $100 \mu \mathrm{l}$ internal standard were added and then the vessel sealed and extracted at $60{ }^{\circ} \mathrm{C}$ in an ultrasonic bath for $60 \mathrm{~min} \pm 2 \mathrm{~min}$. The SPE cartridges were pre-treated with $2 \mathrm{ml} \mathrm{n}$-hexane per $100 \mathrm{mg}$ sorbent. The extraction solution was decanted through the cartridges and the eluate was collected in a new vessel. The cartridge was flushed into the vessel with $5 \mathrm{ml}$ of a 50:50 (v/v) mixture from n- 
hexane and dichloromethane. This solution was concentrated to $1.0 \mathrm{ml}$ under a gentle stream of nitrogen, filtered through a PTFE membrane filter and transferred to a GC-MS vial.

\subsection{3. instrumental analysis}

SCCPs and MCCPs were analyzed using gas chromatography-mass spectrometry (GC-MS, Focus ISQ, ThermoFisher, America) with electron capture negative ionization (ECNI) and selective ion monitor (SIM). SCCPs and MCCPs were detected using two most abundant $[\mathrm{M}-\mathrm{Cl}]^{-}$ isotope ions of each SCCP/MCCP congener for quantification (the most abundant isotope) and identification (the second abundant isotope; the $\mathrm{m} / \mathrm{z}$ of $[\mathrm{M}-\mathrm{Cl}]^{-}$isotope ions of the congeners can be seen in Reth and Oehme ${ }^{1}$. The internal standard was quantified and qualified by $\mathrm{m} / \mathrm{z} 364$ and 362 of the $[\mathrm{M}-\mathrm{Cl}]^{-}$ions respectively. Details of the instrumental analysis procedures are presented in Tables S1.

For the quantification procedure, we followed the method from Reth et al. ${ }^{2}$ to conduct the linear correlation between the total respond factor of SCCP and MCCP standard mixtures and their chlorine content, which can compensate the impact of chlorine content of the standard mixtures on the total respond factor. Moreover, when detecting simultaneously SCCPs and MCCPs at each injection, we carefully determined the selected $[\mathrm{M}-\mathrm{Cl}]^{-}$ions, compared the quantitative and qualitative ion ratios, retention time and chromatographic peak shapes with those of standard mixtures, which can minimize the interference between SCCP and MCCP congeners with the same nominal mass. ${ }^{1}$ 
Tables S1. Chromatography and mass spectrum parameters

\begin{tabular}{|c|c|}
\hline Column: & $\begin{array}{l}5 \% \text { phenyl methyl siloxane, e.g. DB-5 or } \\
\text { equivalent is suitable length: } 25 \mathrm{~m} \text {, } \\
\text { internal diameter: } 0.25 \mathrm{~mm} \\
\text { film thickness: } 0.25 \mu \mathrm{m}\end{array}$ \\
\hline Carrier gas: & helium, flow rate: $1.2 \mathrm{ml} / \mathrm{min}$ \\
\hline Injector temperature: & $250{ }^{\circ} \mathrm{C}$, mode splitless, splitless time: $1.5 \mathrm{~min}$ \\
\hline Injection volume: & $1 \mu 1$ \\
\hline Temperature programme: & $\begin{array}{l}120{ }^{\circ} \mathrm{C} \text {, up to } 300{ }^{\circ} \mathrm{Cat} 12{ }^{\circ} \mathrm{C} / \mathrm{min}, 300{ }^{\circ} \mathrm{C} \text { for } \\
5 \mathrm{~min} \\
\text { solvent delay: } 4 \mathrm{~min} \text {, } \\
\text { total run time: } 20 \mathrm{~min}\end{array}$ \\
\hline MS conditions: & $\begin{array}{l}\text { Transfer line: } 280{ }^{\circ} \mathrm{C} \\
\text { Ion source: } 150{ }^{\circ} \mathrm{C} \\
\text { Quadrupole: } 120^{\circ} \mathrm{C}\end{array}$ \\
\hline $\begin{array}{l}\text { Chemical ionization }(\mathrm{CI}) \\
\text { conditions: }\end{array}$ & $\begin{array}{l}\text { CI gas: Methane } 5.5 \text { (i.e. }>99,9995 \% \mathrm{CH}_{4} \text { ) } \\
\text { CI valve: } 40 \%\end{array}$ \\
\hline
\end{tabular}




\subsubsection{Quality assurance and quality control}

To reduce the possible background pollution, all glass instruments in experiment were soaked in neutral detergent Decon90 diluted with water for more than 6 hours, rinsed with demonized water and placed in a $220^{\circ} \mathrm{C}$ oven dry for more than 12 hours. After that, the package was sealed to prevent contamination and rinsed twice with 1:1 n-hexane/dichloromethane before use. In addition, the SPE purification column was sealed and stored in a glass flask and placed in a desiccator to prevent contamination. Six blank parallel experiments were performed based on GC-ECNI-MS and the recovery rate was calculated to characterize the accuracy of the method. To check the linearity of the analytical system, a calibration standard as reference standard was analyzed after each tenth sample and at the end of the sequence. The deviation in reference to the calibration standard should be within $\pm 20 \%$, otherwise the analytical system has to be checked before retrying the analysis. The recovery rate of SCCPs was 82.6\%-104.2\% and of MCCPs was 86.3\%-96.4\%. The accuracy of the method was also characterized by calculating the relative standard (RSD, $\mathrm{n}=6$ ) deviation of the detected signal, and the average blank value was defined plus three times the standard deviation as method detection limit (MDL). In this work, the MDL of SCCPs and MCCPs was $50 \mathrm{mg} / \mathrm{kg}$. 
Table S2. The details of product samples, concentration ranges of SCCPs and MCCPs in products, and the percentage of detectable samples to total samples $\left(f_{D}\right)$ for products. ("n.d." refers to "not detectable"; the brackets behind the regions means the sample number collected in these regions).

\begin{tabular}{|c|c|c|c|c|c|c|c|c|}
\hline NO. & $\begin{array}{l}\text { Product } \\
\text { samples }\end{array}$ & $\begin{array}{l}\text { Industry } \\
\text { category }\end{array}$ & $\begin{array}{c}\text { Concentrations of } \\
\text { SCCPs and MCCPs } \\
(\mathrm{mg} / \mathrm{g})\end{array}$ & $\begin{array}{l}\text { Sampling } \\
\text { regions }\end{array}$ & $\begin{array}{l}\text { Number } \\
\text { of } \\
\text { samples }\end{array}$ & $\begin{array}{l}\text { Number } \\
\text { of } \\
\text { detectable } \\
\text { samples }\end{array}$ & $f_{D}$ & Graphic examples \\
\hline 1 & $\begin{array}{l}\text { Soft plastic } \\
\text { curtains }\end{array}$ & PVC & $\begin{array}{c}\text { MCCPs: } 36.5-279.1 \\
\text { SCCPs: } 63.7-316.4\end{array}$ & $\begin{array}{l}\text { Guangdong } \\
\text { (5); } \\
\text { Henan (4); } \\
\text { Jiangsu (5) }\end{array}$ & 14 & 14 & $100 \%$ & ГОРәеаАОВГОЭИАЈ \\
\hline 2 & $\begin{array}{l}\text { Hosepipe for } \\
\text { plumbing }\end{array}$ & PVC & $\begin{array}{l}\text { MCCPs: 5.9-192.9 } \\
\text { SCCPs: 5.2-132.2 }\end{array}$ & $\begin{array}{c}\text { Guangdong } \\
\text { (5); } \\
\text { Hebei (5) }\end{array}$ & 10 & 9 & $90 \%$ & $\Longrightarrow$ \\
\hline 3 & $\begin{array}{l}\text { Electrical } \\
\text { cable } \\
\text { sheathing }\end{array}$ & PVC & $\begin{array}{c}\text { MCCPs: 0.1-94.1 } \\
\text { SCCPs: } 0.2-51.8\end{array}$ & $\begin{array}{c}\text { Jiangsu (4); } \\
\text { Zhejiang } \\
\text { (4); } \\
\text { Guangdong } \\
\text { (5) }\end{array}$ & 13 & 13 & $100 \%$ & \\
\hline 4 & $\begin{array}{l}\text { Plastic } \\
\text { flooring }\end{array}$ & PVC & $\begin{array}{c}\text { MCCPs: } 3.1-57.9 \\
\text { SCCPs: } 2.0-11.8\end{array}$ & $\begin{array}{l}\text { Jiangsu (3); } \\
\text { Guangdong } \\
\text { (3) }\end{array}$ & 6 & 3 & $50 \%$ & \\
\hline 5 & Plastic films & PVC & $\begin{array}{l}\text { MCCPs: 0.07-1.6 } \\
\text { SCCPs: } 0.1\end{array}$ & $\begin{array}{l}\text { Zhejiang } \\
\text { (4) }\end{array}$ & 4 & 3 & $75 \%$ & \\
\hline
\end{tabular}




\begin{tabular}{|c|c|c|c|c|c|c|c|}
\hline 6 & Exercise mats & $\begin{array}{l}\text { Rubber and } \\
\text { other plastic }\end{array}$ & $\begin{array}{l}\text { MCCPs: } 1.8-166.9 \\
\text { SCCPs: } 0.6-6.0\end{array}$ & $\begin{array}{c}\text { Shanghai } \\
(1) ; \\
\text { Zhejiang } \\
(2) ; \\
\text { Beijing (2) } \\
\end{array}$ & 5 & 5 & \\
\hline 7 & $\begin{array}{l}\text { Rubber foam } \\
\text { insulation } \\
\text { materials }\end{array}$ & $\begin{array}{l}\text { Rubber and } \\
\text { other plastic }\end{array}$ & $\begin{array}{l}\text { MCCPs: } 22.9-180.6 \\
\text { SCCPs: } 11.7-20.6\end{array}$ & Jiangsu (3) & 5 & 3 & $75 \%$ \\
\hline 8 & $\begin{array}{l}\text { Rubber } \\
\text { protectors }\end{array}$ & $\begin{array}{l}\text { Rubber and } \\
\text { other plastic }\end{array}$ & $\begin{array}{l}\text { MCCPs: } 57.8 \\
\text { SCCPs: } 10.8\end{array}$ & Jiangxi (1) & 2 & 1 & \\
\hline 9 & $\begin{array}{l}\text { Coal } \\
\text { conveyor } \\
\text { belts }\end{array}$ & $\begin{array}{l}\text { Rubber and } \\
\text { other plastic }\end{array}$ & $\begin{array}{c}\text { MCCPs: } 0.1 \\
\text { SCCPs: } 0.09-0.3\end{array}$ & Shangxi (5) & 5 & 3 & $60 \%$ \\
\hline 10 & $\begin{array}{l}\text { Metalworking } \\
\text { fluids }\end{array}$ & $\begin{array}{l}\text { Metalworking } \\
\text { fluids }\end{array}$ & $\begin{array}{l}\text { MCCPs: } 0.08-10.6 \\
\text { SCCPs: } 0.05-0.4\end{array}$ & $\begin{array}{c}\text { Jiangsu (3); } \\
\text { Shandong } \\
(2)\end{array}$ & 5 & 4 & $80 \%$ \\
\hline 11 & $\begin{array}{l}\text { Furniture } \\
\text { materials }\end{array}$ & Leather & $\begin{array}{c}\text { MCCPs: } 5.8-36.9 \\
\text { SCCPs: } 0.8-9.8\end{array}$ & $\begin{array}{l}\text { Zhejiang } \\
\text { (5) }\end{array}$ & 5 & 4 & $80 \%$ \\
\hline
\end{tabular}




\begin{tabular}{|c|c|c|c|c|c|c|c|c|}
\hline 12 & $\begin{array}{l}\text { Garment } \\
\text { materials }\end{array}$ & Leather & $\begin{array}{l}\text { MCCPs: n.d. } \\
\text { SCCPs: } 0.3\end{array}$ & $\begin{array}{c}\text { Guangdong } \\
\text { (4) }\end{array}$ & 4 & 1 & $25 \%$ & \\
\hline 13 & $\begin{array}{l}\text { Polyurethane } \\
\text { foam } \\
\text { adhesives }\end{array}$ & Adhesives & $\begin{array}{c}\text { MCCPs: 46.7-250.8 } \\
\text { SCCPs: } 26.0-123.7\end{array}$ & $\begin{array}{c}\text { Shanghai } \\
\text { (2); } \\
\text { Chongqing } \\
\text { (2); } \\
\text { Tianjin (2) }\end{array}$ & 6 & 5 & $83.33 \%$ & \\
\hline 14 & $\begin{array}{l}\text { Fire retardant } \\
\text { paints }\end{array}$ & Paints/varnishes & $\begin{array}{l}\text { MCCPs: n.d. } \\
\text { SCCPs: n.d. }\end{array}$ & $\begin{array}{c}\text { Beijing (3); } \\
\text { Guangdong } \\
\text { (3); } \\
\text { Anhui (3) }\end{array}$ & 9 & 0 & 0 & \\
\hline 15 & $\begin{array}{l}\text { Waterproof } \\
\text { paints }\end{array}$ & Paints/varnishes & $\begin{array}{l}\text { MCCPs: n.d. } \\
\text { SCCPs: n.d. }\end{array}$ & $\begin{array}{l}\text { Beijing (3); } \\
\text { Anhui (3); } \\
\text { Hebei (3) }\end{array}$ & 9 & 0 & 0 & \\
\hline 16 & $\begin{array}{c}\text { Polyurethane } \\
\text { water } \\
\text { varnishes }\end{array}$ & Paints/varnishes & $\begin{array}{l}\text { MCCPs: n.d. } \\
\text { SCCPs: n.d. }\end{array}$ & $\begin{array}{l}\text { Shanghai } \\
\text { (3) }\end{array}$ & 3 & 0 & 0 & \\
\hline 17 & Tent material & Textiles & $\begin{array}{l}\text { MCCPs: n.d. } \\
\text { SCCPs: n.d. }\end{array}$ & $\begin{array}{c}\text { Zhejiang } \\
\text { (4) }\end{array}$ & 4 & 0 & 0 & \\
\hline
\end{tabular}




\begin{tabular}{|c|c|c|c|c|c|c|c|c|}
\hline 18 & White gauze & Textiles & $\begin{array}{l}\text { MCCPs: n.d. } \\
\text { SCCPs: n.d. }\end{array}$ & $\begin{array}{l}\text { Guangdong } \\
\text { (6) }\end{array}$ & 6 & 0 & 0 & \\
\hline 19 & $\begin{array}{l}\text { Fire- } \\
\text { protection } \\
\text { clothing }\end{array}$ & Textiles & $\begin{array}{l}\text { MCCPs: n.d. } \\
\text { SCCPs: n.d. }\end{array}$ & $\begin{array}{c}\text { Shanghai } \\
\text { (3) }\end{array}$ & 3 & 0 & 0 & \\
\hline 20 & $\begin{array}{l}\text { Surface fabric } \\
\text { for car seat }\end{array}$ & Textiles & $\begin{array}{l}\text { MCCPs: n.d. } \\
\text { SCCPs: n.d. }\end{array}$ & $\begin{array}{c}\text { Guangdong } \\
\text { (3) }\end{array}$ & 3 & 0 & 0 & CANEC2000027401 \\
\hline 21 & $\begin{array}{c}\text { Green } \\
\text { blackout } \\
\text { fabric }\end{array}$ & Textiles & $\begin{array}{l}\text { MCCPs: n.d. } \\
\text { SCCPs: n.d. }\end{array}$ & Jiangxi (3) & 3 & 0 & 0 & \\
\hline
\end{tabular}


Table S3. The concentrations of SCCPs and MCCPs from the existing measurements that are used for estimation in this study.

\begin{tabular}{|c|c|c|c|c|c|c|c|c|}
\hline NO. & Product samples & $\begin{array}{l}\text { Industry } \\
\text { category }\end{array}$ & $\begin{array}{l}\text { Concentrations of SCCPs } \\
\text { and MCCPs }(\mathrm{mg} / \mathrm{g})\end{array}$ & $\begin{array}{l}\text { Sampling } \\
\text { regions }\end{array}$ & $\begin{array}{c}\text { Number } \\
\text { of } \\
\text { samples }\end{array}$ & $\begin{array}{c}\text { Number of } \\
\text { detectable } \\
\text { samples }\end{array}$ & $f_{D}$ & Ref. \\
\hline 3 & Coal conveyor belts & $\begin{array}{l}\text { Rubber and } \\
\text { other plastic }\end{array}$ & $\begin{array}{l}\text { MCCPs: } 22.8 \\
\text { SCCPs: } 13.1\end{array}$ & Beijing (3) & 3 & 1 & $33.3 \%$ & Wang et al. ${ }^{3}$ \\
\hline 6 & Metalworking fluids & $\begin{array}{l}\text { Metalworking } \\
\text { fluids }\end{array}$ & SCCPs: 4.9 & China (5) & 5 & 1 & $20 \%$ & $\mathrm{Xu}$ et al. ${ }^{4}$ \\
\hline 12 & Garment materials & Leather & SCCPs: 0.07 & China & - & - & - & Zhang et al. ${ }^{5}$ \\
\hline 13 & Adhesives & Adhesives & $\begin{array}{l}\text { MCCPs:0.04-220.0 } \\
\text { SCCPs: } 0.06-7.1\end{array}$ & $\begin{array}{c}\text { Jiangsu (2); } \\
\text { Guangzhou } \\
\quad(1) ; \\
\text { Shanghai (1); } \\
\text { Hebei (1) }\end{array}$ & 5 & 5 & $100 \%$ & Xu et al. ${ }^{6}$ \\
\hline
\end{tabular}

-: no information 


\subsection{Production and consumption of products}

Figure S2. Schematic diagram of estimation of production, use and emission of SCCPs and MCCPs.

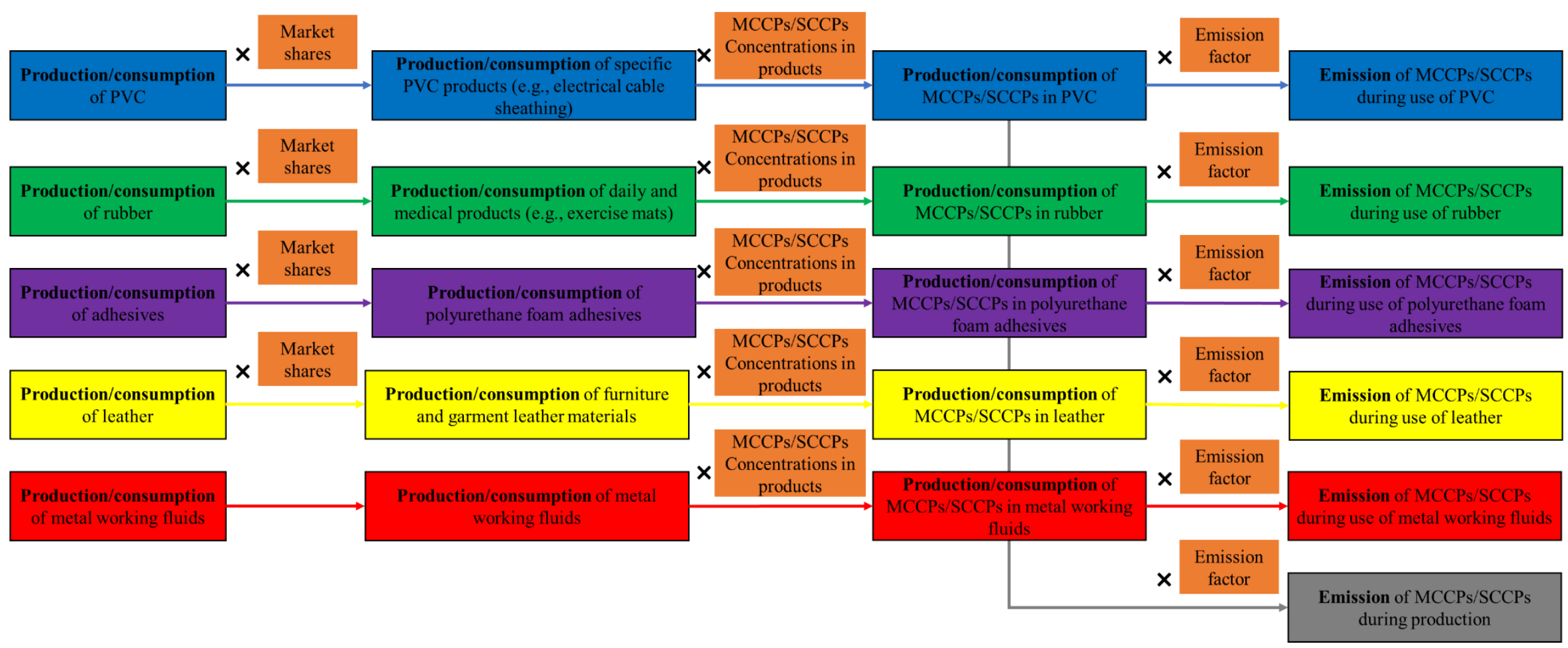


(1). For PVC products, we first derived the annual production and apparent consumption (refers to the use phase) data of PVC from the National Bureau of Statistics of China ${ }^{7}$ (Table S4). We then calculated the amounts of products for electrical cable sheathing, soft plastic curtains, plastic floorings, plastic films that are produced and enter the use phase respectively based on the annual production and apparent consumption and their market shares (\%). The detailed market shares for different products can be seen in Table S6:

$M_{\text {Total_pi }}=M_{p-P V C} \times m s_{i}$

$M_{\text {Total_ci }}=M_{c-P V C} \times m s_{i}$

Where $M_{\text {Total_pi }}$ and $M_{\text {Total_ci }}$ are the amounts of products that are produced and enter the use phase in a given year for product $\mathrm{i}(\mathrm{t})$; $M_{C-P V C}$ and $M_{C-P V C}$ are the amounts of produced and consumed PVC in the given year $(\mathrm{t}) ; m s_{i}$ is the market share of product $\mathrm{i}$ to the total PVC market $(\%)$.

For PVC hosepipes for plumbing, we first derived the production data of plastic pipes in China from 2011-2018. ${ }^{8}$ It is shown that the PVC hosepipes for plumbing cover $5 \%$ of the market of plastic pipes. ${ }^{7}$ Due to the lack of use data, we assumed here that the use of PVC hosepipes for plumbing approximates their production (See detailed data in Table S5).

Summing up all these parts of production and use, we can derive the total amounts of related products that are produced and used for PVC sector.

(2). For rubber plastic products, we first derived the annual production and apparent consumption (referring to use phase) data of rubber $\left(M_{p-\text { rubber }} ; M_{c-\text { rubber }}\right)$ by summing up the production and apparent consumption data of natural and synthetic rubber from the National Bureau of Statistics of China (Table S7) ${ }^{9}$. Due to data lack of the market share for individual products (i.e., exercise mats, rubber foam insulation materials and rubber protectors), we assumed that these products are representative to the daily and medical rubber products and the total market share of daily and medical rubber products is $4 \%$ to the total rubber market. ${ }^{7}$ As such, the amounts of products that are produced and enter the use phase ( $M_{\text {Total_p }}$ and $\left.M_{\text {Total_c }}\right)$ for rubber sector can be calculated as: 
$M_{\text {Total_p }}=M_{p-\text { rubber }} \times 4 \%$

$M_{\text {Total_c }}=M_{c-\text { rubber }} \times 4 \%$

Accordingly, the concentrations of SCCPs/MCCPs in these rubber products (i.e., $C_{\mathrm{SCCP} / \mathrm{MCCPs}}$ ) were the maximum-minimum values of the highest and lowest concentrations of these detected samples. It should be noted that major uncertainty may exist for this assumption because the sampled products (i.e., exercise mats, rubber foam insulation materials and rubber protectors) cannot represent all of the daily and medical rubber products.

For rubber coal conveyor belts, we first derived the production of industry conveyor belts from China National Light Industry Associations, ${ }^{10}$ in which the rubber coal conveyor belts cover $40 \%$ of the total market. Here, we assumed that the use of rubber coal conveyor belts approximates their production. The detailed data and data processing can be seen in Table S8.

Summing up these two parts of production and use, we can derive the total amounts of related products that are produced and used for rubber sector.

(3). For leather materials, we derived the annual production data of leather $\left(M_{p \text {-leather }}\right)$ (Table S9), ${ }^{11}$ among which furniture materials and garment materials cover $12 \%$ and $15 \%$ respectively. ${ }^{7}$ We assumed the use of leather materials approximates their productions.

For furniture materials,

$M_{\text {Total_p }}=M_{p \text {-leather }} \times 12 \%$

$M_{\text {Total_c }}=M_{p-\text { leather }} \times 12 \%$

For garment materials,

$M_{\text {Total_p }}=M_{p-\text { leather }} \times 15 \%$ 
Summing up these two parts of production and use, we can derive the total amounts of related products that are produced and used for leather sector.

(4). The annual production and apparent consumption (referring to the use phase) data of metalworking fluids can be derived directly from the Chinese Oil Industry Association. ${ }^{12}$ The detailed data are shown in Table S10.

(5). For polyurethane foam adhesives, we derived the annual production and apparent consumption (referring to the use phase) data of total adhesives from the China Adhesives and Tape Industry Association (Table S11). ${ }^{13}$ The production of total adhesives in 2010 is $4,628,000$ tons, among which the production of structural adhesives is 329,600 tons. In addition, the market share of polyurethane foam adhesives in structural adhesives is $18 \%$ in 2010 . Therefore, the market share of polyurethane foam adhesives in total adhesives goes to $1.3 \%$ in 2010. We assumed that this market share is constant with time, and thus the annual production and consumption data of polyurethane foam adhesives can be calculated as:

$M_{\text {Total_p }}=M_{p-\text { adhesives }} \times 1.3 \%$

$M_{\text {Total_c }}=M_{c \text {-adhesives }} \times 1.3 \%$ 
Table S4. The annual production and apparent consumption of PVC in China during 2000-2019 (10 kilotons). ${ }^{7}$

\begin{tabular}{cccccc}
\hline Year & Production & Apparent consumption & Years & Production & Apparent consumption \\
\hline 2000 & 155.5 & $388.5^{*}$ & 2010 & 1130.1 & 1254.6 \\
2001 & 253.8 & $471.9^{*}$ & 2011 & 1295.2 & 1382.7 \\
2002 & 338.9 & 560.2 & 2012 & 1317.8 & 1393.3 \\
2003 & 400.6 & 625.4 & 2013 & 1529.5 & 1560.6 \\
2004 & 503.2 & 709.9 & 2014 & 1629.6 & 1602.9 \\
2005 & 649.2 & 800.4 & 2015 & 1609.2 & 1614.4 \\
2006 & 823.9 & 919.1 & 2016 & 1669.2 & 1639.2 \\
2007 & 971.7 & 1026.8 & 2017 & 1790.2 & 1781.2 \\
2008 & 881.7 & 929.8 & 2018 & 1890.4 & 1902.2 \\
2009 & 915.5 & 1083.5 & 2019 & 2022.2 & 1973.5 \\
\hline
\end{tabular}

*The data gaps for Year 2000-2001 and 2019 were interpolated based on the linear fitting of existing data.

Table S5. The annual production of plastic pipes ${ }^{8}$ and PVC hosepipes for plumping (10 kilotons). The annual production of PVC hosepipes in plumping is calculated based on the equation: $M_{\mathrm{PVC} \text { hosepipe in plumping }}=M_{\text {plastic pipe }} \times 5 \%{ }^{7}$

\begin{tabular}{cccccc}
\hline Year & Plastic pipes & PVC hosepipes for plumping & Years & Plastic pipes & PVC hosepipes for plumping \\
\hline 2000 & -- & $4.4^{*}$ & 2010 & -- & $46.9^{*}$ \\
2001 & -- & $8.6^{*}$ & 2011 & 1000 & 50.0 \\
2002 & -- & $12.9^{*}$ & 2012 & 1100 & 55.0 \\
2003 & -- & $17.1^{*}$ & 2013 & 1210 & 60.5 \\
2004 & -- & $21.4^{*}$ & 2014 & 1300 & 65.0 \\
2005 & -- & $25.6^{*}$ & 2015 & 1380 & 69.0 \\
2006 & -- & $29.9^{*}$ & 2016 & 1436 & 71.8 \\
2007 & -- & $34.1^{*}$ & 2017 & 1522 & 76.1 \\
2008 & -- & $38.4^{*}$ & 2018 & 1610 & 80.5 \\
2009 & -- & $42.6^{*}$ & 2019 & -- & $85.1^{*}$ \\
\hline
\end{tabular}


* The data gaps for Year 2000-2010 and 2019 were interpolated based on the linear fitting of annual production data of PVC hosepipes for plumping from other years.

Table S6. Market shares of PVC products to total PVC market from different years. We assumed that the market shares for 2000-2007 are the same as that for 2007; the market shares for 2009-2012 are the same as that of 2010; the market shares for 2013-2016 are the same as 2014; and the market shares for 2019 are the same as that for 2019. Due to the lack of market share for soft plastic curtains, we used the market share from Europe as alternative.

\begin{tabular}{|c|c|c|c|c|c|c|c|c|}
\hline Year & $\begin{array}{l}\text { Electrical cable } \\
\text { sheathing }\end{array}$ & Ref. & $\begin{array}{c}\text { Plastic } \\
\text { floorings }\end{array}$ & Ref. & $\begin{array}{l}\text { Plastic } \\
\text { films }\end{array}$ & Ref. & $\begin{array}{l}\text { Soft plastic } \\
\text { curtains }\end{array}$ & Ref. \\
\hline $2000-2008$ & $7 \%$ & 14 & $2.1 \%$ & 14 & $12 \%$ & 14 & $0.6 \%$ & 15 \\
\hline 2009-2012 & $5.1 \%$ & 16 & $1.8 \%$ & 16 & $11.95 \%$ & 16 & $0.6 \%$ & 15 \\
\hline 2013-2016 & $6 \%$ & 17 & $3 \%$ & 17 & $6 \%$ & 17 & $0.6 \%$ & 15 \\
\hline 2017 & $6 \%$ & 18 & $5 \%$ & 18 & $8 \%$ & 18 & $0.6 \%$ & 15 \\
\hline 2018-2019 & $6 \%$ & 19 & $7 \%$ & 19 & $9 \%$ & 19 & $0.6 \%$ & 15 \\
\hline
\end{tabular}

Table S7. The annual production and apparent consumption of natural and synthetic rubber (10 kilotons). ${ }^{9}$

\begin{tabular}{|c|c|c|c|c|c|c|}
\hline Year & $\begin{array}{l}\text { Production of } \\
\text { natural rubber }\end{array}$ & $\begin{array}{l}\text { Apparent consumption } \\
\text { of natural rubber }\end{array}$ & $\begin{array}{l}\text { Production of } \\
\text { synthetic rubber }\end{array}$ & $\begin{array}{l}\text { Apparent consumption of } \\
\text { synthetic rubber }\end{array}$ & $\begin{array}{c}\text { Summed } \\
\text { production of } \\
\text { rubber }\end{array}$ & $\begin{array}{c}\text { Summed } \\
\text { apparent } \\
\text { consumption } \\
\text { of rubber }\end{array}$ \\
\hline 2000 & $17.0^{1}$ & $54.9^{*}$ & 83.6 & $49.2^{*}$ & 138.5 & 104.1 \\
\hline 2001 & $22.1^{1}$ & $83.0^{*}$ & 104.6 & $88.6^{*}$ & 126.7 & 171.6 \\
\hline 2002 & $27.3^{1}$ & $111.1^{*}$ & 116.8 & $127.9^{*}$ & 144.1 & 239.0 \\
\hline 2003 & $32.5^{1}$ & $139.3^{*}$ & 127.2 & $167.2^{*}$ & 159.7 & 306.5 \\
\hline 2004 & $37.7^{1}$ & $167.4^{*}$ & 147.7 & $206.5^{*}$ & 185.4 & 373.9 \\
\hline 2005 & $42.9^{1}$ & $195.5^{*}$ & 163.2 & 272.1 & 206.1 & 467.6 \\
\hline 2006 & $48.0^{1}$ & $223.6^{*}$ & 184.5 & 235.5 & 232.6 & 459.1 \\
\hline
\end{tabular}




\begin{tabular}{|c|c|c|c|c|c|c|}
\hline 2007 & $53.2^{1}$ & $251.7^{*}$ & 221.5 & 354.6 & 274.7 & 606.3 \\
\hline 2008 & $58.4^{1}$ & $279.9^{*}$ & 238.3 & 348.3 & 296.7 & 628.2 \\
\hline 2009 & $63.6^{1}$ & $308.0^{*}$ & 275.5 & 411.9 & 339.1 & 719.9 \\
\hline 2010 & 68.7 & $336.1^{*}$ & 310.0 & 442.8 & 378.7 & 778.9 \\
\hline 2011 & 72.7 & 360.0 & 348.8 & $481.8^{*}$ & 421.5 & 841.8 \\
\hline 2012 & 80.0 & 386.5 & 378.6 & $521.2^{*}$ & 458.6 & 907.7 \\
\hline 2013 & 86.5 & 423.4 & 409.0 & $560.5^{*}$ & 495.5 & 983.9 \\
\hline 2014 & 87.7 & 476.0 & 532.4 & $599.8^{*}$ & 620.1 & 1075.8 \\
\hline 2015 & 82.0 & 464.6 & 516.6 & $639.2^{*}$ & 598.6 & 1103.8 \\
\hline 2016 & 76.4 & 489.6 & 545.8 & $678.5^{*}$ & 622.2 & 1168.1 \\
\hline 2017 & 81.6 & 540.0 & 578.7 & $717.8^{*}$ & 660.3 & 1257.8 \\
\hline 2018 & $86.8^{2}$ & $561.1^{*}$ & 559.0 & $757.2^{*}$ & 645.8 & 1318.2 \\
\hline 2019 & $92.0^{2}$ & $589.2^{*}$ & 560.0 & $796.5^{*}$ & 652.0 & 1385.7 \\
\hline
\end{tabular}

* The data with "*" were interpolated based on the linear fitting of existing data from other years.

1,2: The data of production of natural rubber suggest different trends between 2010-2014 and 2015-2017, so we interpolated the data of 20002009 by linear fitting of 2010-2014 (marked as “"”); and interpolated the data of 2018-2019 by linear fitting of 2015-2017 (Marked as “2"”).

Table S8. The annual production of industry conveyor belts and rubber coal conveyor belts. ${ }^{10}$

\begin{tabular}{|c|c|c|c|c|c|c|c|}
\hline Year & $\begin{array}{c}\text { Industry } \\
\text { conveyor } \\
\text { belts }(10,000 \\
\text { square } \\
\text { meters })\end{array}$ & $\begin{array}{l}\text { Rubber coal } \\
\text { conveyor } \\
\text { belts }(10,000 \\
\text { square } \\
\text { meters })^{1}\end{array}$ & $\begin{array}{c}\text { Rubber coal } \\
\text { conveyor } \\
\text { belts }(10 \\
\text { kilotons })^{2}\end{array}$ & Year & $\begin{array}{c}\text { Industry } \\
\text { conveyor } \\
\text { belts } \\
(10,000 \\
\text { square } \\
\text { meters })\end{array}$ & $\begin{array}{c}\text { Rubber } \\
\text { coal } \\
\text { conveyor } \\
\text { belts } \\
(10,000 \\
\text { square } \\
\text { meters })^{1}\end{array}$ & $\begin{array}{l}\text { Rubber } \\
\text { coal } \\
\text { conveyor } \\
\text { belts }(10 \\
\text { kilotons })^{2}\end{array}$ \\
\hline 2000 & -- & -- & 0 * & 2010 & 29935 & 11974.0 & 18.7 \\
\hline 2001 & -- & -- & $0^{*}$ & 2011 & 34838 & 13935.2 & 21.7 \\
\hline 2002 & -- & -- & $0^{*}$ & 2012 & 41005 & 16402.0 & 25.6 \\
\hline 2003 & -- & -- & $0^{*}$ & 2013 & 43675 & 17470.0 & 27.3 \\
\hline 2004 & -- & -- & $1.9^{*}$ & 2014 & 49235 & 19694.0 & 30.7 \\
\hline 2005 & -- & -- & $4.7^{*}$ & 2015 & 53654 & 21461.6 & 33.5 \\
\hline 2006 & -- & -- & $7.6^{*}$ & 2016 & 57744 & 23097.6 & 36.0 \\
\hline 2007 & -- & -- & $10.5^{*}$ & 2017 & 62733 & 25093.2 & 39.1 \\
\hline
\end{tabular}




\begin{tabular}{llllllrr}
\hline 2008 & -- & -- & $13.3^{*}$ & 2018 & 66987 & 26794.8 & 41.8 \\
2009 & -- & -- & $16.2^{*}$ & 2019 & -- & -- & $44.8^{*}$ \\
\hline
\end{tabular}

1: The annual production of rubber coal conveyor belts covers $40 \%$ of that of industry conveyor belts (10,000 square meters.)

2: According to the Document GB/T 4490-1994, the average mass of rubber coal conveyor belts per 10,000 square meters is 15.6 tons.

*: The data were interpolated based on the linear fitting of the annual production of rubber coal conveyor belts of Year $2010-2018$.

Table S9. The annual production of leather $\left(M_{p \text {-leather }}\right){ }^{11}$

\begin{tabular}{|c|c|c|c|c|c|}
\hline Year & $\begin{array}{l}\text { Production of } \\
\text { leather ( } 100 \\
\text { million square } \\
\text { meters) }\end{array}$ & $\begin{array}{c}\text { Production of } \\
\text { leather }(10 \\
\text { kilotons })^{1}\end{array}$ & Year & $\begin{array}{l}\text { Production of } \\
\text { leather (100 } \\
\text { million square } \\
\text { meters) }\end{array}$ & $\begin{array}{c}\text { Production of } \\
\text { leather }(10 \\
\text { kilotons })^{1}\end{array}$ \\
\hline 2000 & 3.5 & 57.3 & 2010 & 7.5 & 123.6 \\
\hline 2001 & 4.2 & 69.0 & 2011 & 6.9 & 113.2 \\
\hline 2002 & 4.8 & 79.0 & 2012 & 7.5 & 123.3 \\
\hline 2003 & 4.8 & 78.7 & 2013 & 5.5 & 91.0 \\
\hline 2004 & 5.1 & 84.2 & 2014 & 5.9 & 98.0 \\
\hline 2005 & 5.5 & 89.9 & 2015 & 6.0 & 99.0 \\
\hline 2006 & 7.2 & 119.5 & 2016 & 7.4 & 121.3 \\
\hline 2007 & 6.8 & 112.9 & 2017 & 6.3 & 104.0 \\
\hline 2008 & 6.4 & 105.9 & 2018 & 5.0 & 81.8 \\
\hline 2009 & 6.9 & 114.2 & 2019 & $7.0^{*}$ & $116.1^{*}$ \\
\hline
\end{tabular}

1: The average mass of leather per 10,000 square meters is 16.5 tons.

*: The data were interpolated based on the linear fitting of the data of Year 2000-2018.

Table S10. The annual production and apparent consumption of metalworking fluids (10 kilotons). ${ }^{12}$

\begin{tabular}{cccccc}
\hline Year & Production & $\begin{array}{c}\text { Apparent } \\
\text { consumption }\end{array}$ & Year & Production & $\begin{array}{c}\text { Apparent } \\
\text { consumption }\end{array}$ \\
\hline 2000 & $0^{*}$ & $0^{*}$ & 2010 & 45.2 & 51.2 \\
2001 & $0^{*}$ & $0^{*}$ & 2011 & 54.2 & 59.4 \\
2002 & $0^{*}$ & $0^{*}$ & 2012 & 62.5 & 68.0 \\
2003 & $0^{*}$ & $4.5^{*}$ & 2013 & 72.8 & $73.5^{*}$ \\
2004 & $0.4^{*}$ & $11.4^{*}$ & 2014 & 82.3 & $80.4^{*}$ \\
2005 & $8.3^{*}$ & $18.3^{*}$ & 2015 & $87.5^{*}$ & $87.3^{*}$ \\
\hline
\end{tabular}




\begin{tabular}{llllll}
\hline 2006 & $16.2^{*}$ & $25.2^{*}$ & 2016 & $95.4^{*}$ & $94.2^{*}$ \\
2007 & 28.5 & 33.5 & 2017 & $106.7^{*}$ & $101.1^{*}$ \\
2008 & 32.2 & 38.2 & 2018 & $111.2^{*}$ & $108.0^{*}$ \\
2009 & 37.1 & 45.8 & 2019 & $119.1^{*}$ & $114.9^{*}$ \\
\hline
\end{tabular}

*: The data of production and apparent consumption were interpolated based on the linear fitting of existing data of production and apparent consumption respectively.

Table S11. The annual production and apparent consumption of total adhesives and polyurethane foam adhesives (10 kilotons). ${ }^{13}$

\begin{tabular}{ccccc}
\hline Year & $\begin{array}{c}\text { Production of total } \\
\text { adhesives }\end{array}$ & $\begin{array}{c}\text { Production of } \\
\text { polyurethane foam } \\
\text { adhesives }\end{array}$ & $\begin{array}{c}\text { Apparent } \\
\text { consumption of } \\
\text { total adhesives }\end{array}$ & $\begin{array}{c}\text { Apparent } \\
\text { consumption of } \\
\text { polyurethane } \\
\text { foam adhesives }\end{array}$ \\
\hline 2000 & -- & $0.2^{*}$ & -- & $0^{*}$ \\
2001 & -- & $0.8^{*}$ & -- & $0.3^{*}$ \\
2002 & -- & $1.4^{*}$ & -- & $0.9^{*}$ \\
2003 & -- & $2.0^{*}$ & -- & $1.5^{*}$ \\
2004 & 227.9 & 2.9 & -- & $2.1^{*}$ \\
2005 & 251.7 & 3.2 & -- & $3.3^{*}$ \\
2006 & 280.0 & 3.6 & -- & $3.9^{*}$ \\
2007 & 332.5 & 4.3 & -- & $4.6^{*}$ \\
2008 & 357.0 & 4.6 & -- & 5.1 \\
2009 & 405.0 & 5.2 & 395.0 & 5.8 \\
2010 & 462.8 & 5.9 & 453.0 & 6.4 \\
2011 & 516.5 & 6.6 & 502.0 & 7.0 \\
2012 & 560.5 & 7.2 & 544.0 & 7.6 \\
2013 & 611.2 & 7.8 & 592.0 & 8.3 \\
2014 & 658.7 & 8.4 & 650.0 & 8.7 \\
2015 & 686.8 & 8.8 & 676.0 & 9.2 \\
2016 & 733.9 & 9.4 & 721.0 & 10.1 \\
2017 & 796.2 & 10.2 & 788.0 & 10.6 \\
2018 & 838.3 & 10.7 & 827.1 & $11.2^{*}$ \\
2019 & -- & $11.2 *$ & -- & $279 \%$ of \\
\hline
\end{tabular}

${ }^{1}$ : The annual production and apparent consumption of polyurethane foam adhesives are $1.279 \%$ of that of total adhesives respectively. 
*: The data of production and apparent consumption were interpolated based on the linear fitting of existing data of production and apparent consumption for polyurethane foam adhesives respectively.

Table S12. The emission factors of SCCPs during production and use, which are summarized by Glüge et al. ${ }^{20}$

\begin{tabular}{|c|c|c|c|c|}
\hline Stages & To air & $\begin{array}{c}\text { To surface } \\
\text { water }\end{array}$ & To soil & $\begin{array}{l}\text { Product } \\
\text { lifetime }\end{array}$ \\
\hline Production & $0 \%-0.004 \%$ & $0.01 \%$ & $0.01 \%$ & \\
\hline \multicolumn{5}{|c|}{ Use as plasticizer/flame retardant in PVC } \\
\hline Formulation & $0.02 \%$ & $0.01 \%$ & \multirow{3}{*}{$0.05 \%$} & \\
\hline Polymer processing & $0.06 \%-1 \%$ & $0.1 \%$ & & \\
\hline Emission over lifetime & $0.05 \%$ & $0.05 \%$ & & $10-20$ years \\
\hline \multicolumn{5}{|c|}{ Use as plasticizer/flame retardant in other plastic and rubber } \\
\hline Formulation & $0.005 \%$ & $0.015 \%$ & & \\
\hline Polymer processing & $0.005 \%-0.1 \%$ & $0.005 \%-0.05 \%$ & $0.01 \%$ & \\
\hline Emission over lifetime & $0.05 \%$ & $0.25 \%$ & $4 \%$ & 5-15 years \\
\hline \multicolumn{5}{|c|}{ Use as plasticizer/flame retardant in sealants/adhesives } \\
\hline Formulation & \multicolumn{4}{|c|}{$0 \%$} \\
\hline Emission over lifetime & $0.05 \%-0.25 \%$ & $15 \%$ & $4 \%-10 \%$ & $10-30$ years \\
\hline \multicolumn{5}{|c|}{$\begin{array}{l}\text { Use as extreme pressure additives and boundary lubricants in } \\
\text { metalworking fluids }\end{array}$} \\
\hline Formulation & $0.005 \%$ & $0.2 \%-0.25 \%$ & \multirow{2}{*}{\multicolumn{2}{|c|}{$\begin{array}{c}0.001 \% \\
0 \%-0.01 \%\end{array}$}} \\
\hline Industrial use & $0 \%-0.02 \%$ & $10 \%-22.8 \%$ & & \\
\hline \multicolumn{5}{|c|}{ Use as fat liquoring agents in leather treatments } \\
\hline Formulation & $0.1 \%$ & $2 \%$ & \multirow{2}{*}{\multicolumn{2}{|c|}{$\begin{array}{c}0.01 \% \\
1 \%\end{array}$}} \\
\hline Industrial use & $0.1 \%$ & $1 \%-5 \%$ & & \\
\hline
\end{tabular}


Table S13. The emission factors of MCCPs during production and use.

\begin{tabular}{|c|c|c|c|c|}
\hline Stages & To air & $\begin{array}{l}\text { To surface } \\
\text { water }\end{array}$ & To soil & $\begin{array}{l}\text { Product } \\
\text { lifetime }\end{array}$ \\
\hline Production & $\begin{array}{l}0.001 \%^{1}- \\
0.004 \%^{1}\end{array}$ & $0.30 \%{ }^{2}$ & $0.01 \%{ }^{1}$ & \\
\hline \multicolumn{5}{|c|}{ Use as plasticizer/flame retardant in PVC } \\
\hline Formulation & $0.02 \%{ }^{2}$ & $0.01 \%{ }^{2}$ & \multirow{3}{*}{$0.05 \%{ }^{2}$} & \\
\hline Polymer processing & $0.06 \%^{2}-1 \%{ }^{2}$ & $0.1 \%^{2}$ & & \\
\hline Emission over lifetime & $0.05 \%{ }^{2}$ & $0.05 \%{ }^{2}$ & & $10-20$ years $^{3}$ \\
\hline \multicolumn{5}{|c|}{ Use as plasticizer/flame retardant in other plastic and rubber } \\
\hline Formulation & $0.01 \%{ }^{2}$ & $0.01 \%{ }^{2}$ & \\
\hline Polymer processing & $0.006 \%{ }^{4}-0.1 \% 5$ & $0.05 \% 5$ & $0.01 \% 5$ & \\
\hline Emission over lifetime & $0.05 \%{ }^{2}$ & $0 \%{ }^{2}$ & $4 \%^{6}$ & $5-15$ years $^{3}$ \\
\hline \multicolumn{5}{|c|}{ Use as plasticizer/flame retardant in sealants/adhesives } \\
\hline Formulation & \multicolumn{4}{|c|}{$0 \%^{2}$} \\
\hline Emission over lifetime & $0.05 \%{ }^{2}$ & $0.15 \%{ }^{2}$ & $4 \%^{6}-10 \%{ }^{6}$ & $10-30$ years $^{3}$ \\
\hline \multicolumn{5}{|c|}{$\begin{array}{c}\text { Use as extreme pressure additives and boundary lubricants in } \\
\text { metalworking fluids }\end{array}$} \\
\hline Formulation & $0.005 \%{ }^{2}$ & $0.2 \%^{2}-0.25 \%^{2}$ & \multirow{2}{*}{\multicolumn{2}{|c|}{$\begin{array}{l}0.001 \%^{5} \\
0.01 \%\end{array}$}} \\
\hline Industrial use & $0 \%{ }^{2}-0.02 \% \%^{5}$ & $10 \%{ }^{7}-31.6 \%{ }^{5}$ & & \\
\hline \multicolumn{5}{|c|}{ Use as fat liquoring agents in leather treatments } \\
\hline Formulation & $0.1 \%{ }^{2}$ & $0.3 \%^{2}-2 \%{ }^{5}$ & \multicolumn{2}{|l|}{$0.01 \%{ }^{5}$} \\
\hline Industrial use & $0.1 \%{ }^{5}$ & $2 \%^{2}-5 \%{ }^{5}$ & $1 \%{ }^{2}$ & \\
\hline
\end{tabular}

1: Back et al. ${ }^{21}$;

Industrial use

$0.1 \%$

$2 \%^{2}-5 \%^{5}$

$1 \%^{2}$

2: European Chemical Bureau ${ }^{22}$;

3: Glüge et al. ${ }^{20}$; 
4: $\mathrm{KEMI}^{23}$;

5: Default values recommended by European Chemical Bureau ${ }^{24}$;

6: Values for SCCPs from European Chemical Agency ${ }^{25}$;

7: U.S. Environmental Protection Agency ${ }^{26}$

\section{Results and discussion}

Table S14. The maximum and minimum values of production of SCCPs and MCCPs in China in 2018 and 2019 (kt).

\begin{tabular}{|c|c|c|c|c|c|c|c|c|}
\hline & \multicolumn{4}{|c|}{ SCCPs } & \multicolumn{4}{|c|}{ MCCPs } \\
\hline & \multicolumn{2}{|c|}{2018} & \multicolumn{2}{|c|}{2019} & \multicolumn{2}{|c|}{2018} & \multicolumn{2}{|c|}{2019} \\
\hline & Max & Min & $\operatorname{Max}$ & Min & Max & Min & $\operatorname{Max}$ & Min \\
\hline PVC & 198.3 & 12.6 & 211.0 & 13.4 & 318.5 & 10.7 & 338.9 & 11.4 \\
\hline Rubber & 6.7 & 0.03 & 7.0 & 0.03 & 39.8 & 0.4 & 40.4 & 0.4 \\
\hline Leather & 0.8 & 0.1 & 1.1 & 0.1 & 2.9 & 0.5 & 4.1 & 0.6 \\
\hline Metalworking fluids & 2.7 & 0.03 & 2.9 & 0.03 & 5.9 & 0.04 & 6.3 & 0.04 \\
\hline $\begin{array}{c}\text { Polyurethane foam } \\
\text { adhesives }\end{array}$ & 12.1 & 0.01 & 12.6 & 0.01 & 24.4 & 0.004 & 25.5 & 0.004 \\
\hline Sum & 220.7 & 12.7 & 234.6 & 13.6 & 391.5 & 12.7 & 415.3 & 12.5 \\
\hline
\end{tabular}


Table S15. The maximum and minimum values of use of SCCPs and MCCPs in China in 2018 and 2019 (kt).

\begin{tabular}{|c|c|c|c|c|c|c|c|c|}
\hline & \multicolumn{4}{|c|}{ SCCPs } & \multicolumn{4}{|c|}{ MCCPs } \\
\hline & \multicolumn{2}{|c|}{2018} & \multicolumn{2}{|c|}{2019} & \multicolumn{2}{|c|}{2018} & \multicolumn{2}{|c|}{2019} \\
\hline & $\operatorname{Max}$ & Min & Max & Min & $\operatorname{Max}$ & Min & $\operatorname{Max}$ & Min \\
\hline PVC & 199.0 & 12.7 & 208.3 & 13.2 & 319.6 & 10.8 & 334.3 & 11.2 \\
\hline Rubber & 10.9 & 0.04 & 11.5 & 0.05 & 76.2 & 0.7 & 80.2 & 0.8 \\
\hline Leather & 0.8 & 0.1 & 1.1 & 0.1 & 2.9 & 0.5 & 4.1 & 0.6 \\
\hline Metalworking fluids & 2.7 & 0.03 & 2.8 & 0.03 & 5.7 & 0.04 & 6.1 & 0.04 \\
\hline $\begin{array}{l}\text { Polyurethane foam } \\
\text { adhesives }\end{array}$ & 11.9 & 0.01 & 12.6 & 0.01 & 24.1 & 0.004 & 25.5 & 0.004 \\
\hline Sum & 225.2 & 12.8 & 236.4 & 13.4 & 428.5 & 12.0 & 450.2 & 12.7 \\
\hline
\end{tabular}


Table S16. The maximum values of emission of SCCPs and MCCPs in China in 2018 and 2019 (kt).

\begin{tabular}{|c|c|c|c|c|c|c|c|c|c|c|c|c|}
\hline & \multicolumn{6}{|c|}{ SCCPs } & \multicolumn{6}{|c|}{ MCCPs } \\
\hline & & 2018 & & & 2019 & & & 2018 & & & 2019 & \\
\hline & Air & $\begin{array}{l}\text { Surface } \\
\text { water }\end{array}$ & Soils & Air & $\begin{array}{l}\text { Surface } \\
\text { water }\end{array}$ & Soils & Air & $\begin{array}{l}\text { Surface } \\
\text { water }\end{array}$ & Soils & Air & $\begin{array}{l}\text { Surface } \\
\text { water }\end{array}$ & Soils \\
\hline Production & $8.8 \mathrm{E}-03$ & $1.8 \mathrm{E}-04$ & $2.2 \mathrm{E}-02$ & $9.4 \mathrm{E}-03$ & $1.9 \mathrm{E}-04$ & $2.3 \mathrm{E}-02$ & $1.6 \mathrm{E}-02$ & $9.4 \mathrm{E}-04$ & $3.9 \mathrm{E}-02$ & $1.7 \mathrm{E}-02$ & $1.0 \mathrm{E}-03$ & $4.2 \mathrm{E}-02$ \\
\hline PVC & $2.1 \mathrm{E}+00$ & $2.2 \mathrm{E}-03$ & 9.9E-02 & $2.2 \mathrm{E}+00$ & $2.3 \mathrm{E}-03$ & $1.0 \mathrm{E}-01$ & $3.5 \mathrm{E}-01$ & $3.5 \mathrm{E}-03$ & $1.6 \mathrm{E}-01$ & $3.6 \mathrm{E}-01$ & $3.7 \mathrm{E}-03$ & $1.7 \mathrm{E}-01$ \\
\hline Rubber & $1.5 \mathrm{E}-02$ & $1.9 \mathrm{E}-04$ & $2.7 \mathrm{E}-01$ & $1.6 \mathrm{E}-02$ & $2.1 \mathrm{E}-04$ & 2.9E-01 & $1.1 \mathrm{E}-01$ & $3.7 \mathrm{E}-04$ & $2.0 \mathrm{E}+00$ & $1.1 \mathrm{E}-01$ & 3.8E-04 & $2.1 \mathrm{E}+00$ \\
\hline Leather & $1.6 \mathrm{E}-03$ & $4.4 \mathrm{E}-04$ & 7.9E-03 & $2.2 \mathrm{E}-03$ & $6.2 \mathrm{E}-04$ & $1.1 \mathrm{E}-02$ & $3.2 \mathrm{E}-03$ & $1.6 \mathrm{E}-03$ & $2.9 \mathrm{E}-02$ & $4.5 \mathrm{E}-03$ & $2.3 \mathrm{E}-03$ & $4.2 \mathrm{E}-02$ \\
\hline $\begin{array}{l}\text { Metalworking } \\
\text { fluids }\end{array}$ & $6.7 \mathrm{E}-04$ & $4.9 \mathrm{E}-03$ & $2.9 \mathrm{E}-04$ & $7.1 \mathrm{E}-04$ & $5.2 \mathrm{E}-03$ & $3.1 \mathrm{E}-04$ & $1.4 \mathrm{E}-03$ & $1.5 \mathrm{E}-02$ & $6.3 \mathrm{E}-04$ & $1.5 \mathrm{E}-03$ & $1.5 \mathrm{E}-02$ & 6.7E-04 \\
\hline $\begin{array}{c}\text { Polyurethane foam } \\
\text { adhesives }\end{array}$ & $1.4 \mathrm{E}-02$ & $8.2 \mathrm{E}-01$ & $5.4 \mathrm{E}-01$ & $1.5 \mathrm{E}-02$ & 8.9E-01 & $5.9 \mathrm{E}-01$ & $1.8 \mathrm{E}-02$ & $1.7 \mathrm{E}-02$ & $1.1 \mathrm{E}+00$ & $1.9 \mathrm{E}-02$ & $1.8 \mathrm{E}-02$ & $1.2 \mathrm{E}+00$ \\
\hline Sum & $2.1 \mathrm{E}+00$ & 8.2E-01 & $9.5 \mathrm{E}-01$ & $2.2 \mathrm{E}+00$ & $9.0 \mathrm{E}-01$ & $1.0 \mathrm{E}+00$ & 4.9E-01 & $3.8 \mathrm{E}-02$ & $3.3 \mathrm{E}+00$ & $5.2 \mathrm{E}-01$ & 4.1E-02 & $3.5 \mathrm{E}+00$ \\
\hline
\end{tabular}


Table S17. The minimum values of emission of SCCPs and MCCPs in China in 2018 and 2019 (kt).

\begin{tabular}{|c|c|c|c|c|c|c|c|c|c|c|c|c|}
\hline & \multicolumn{6}{|c|}{ SCCPs } & \multicolumn{6}{|c|}{ MCCPs } \\
\hline & Air & $\begin{array}{l}\text { Surface } \\
\text { water }\end{array}$ & Soils & Air & $\begin{array}{l}\text { Surface } \\
\text { water }\end{array}$ & Soils & Air & $\begin{array}{l}\text { Surface } \\
\text { water }\end{array}$ & Soils & Air & $\begin{array}{l}\text { Surface } \\
\text { water }\end{array}$ & Soils \\
\hline Production & $0.0 \mathrm{E}+00$ & $1.0 \mathrm{E}-05$ & $1.3 \mathrm{E}-03$ & $0.0 \mathrm{E}+00$ & $1.1 \mathrm{E}-05$ & $1.4 \mathrm{E}-03$ & $1.2 \mathrm{E}-04$ & $2.8 \mathrm{E}-05$ & $1.2 \mathrm{E}-03$ & $1.2 \mathrm{E}-04$ & $3.0 \mathrm{E}-05$ & $1.2 \mathrm{E}-03$ \\
\hline $\mathrm{PVC}$ & $1.4 \mathrm{E}-02$ & $1.5 \mathrm{E}-04$ & $6.3 \mathrm{E}-03$ & $1.5 \mathrm{E}-02$ & $1.5 \mathrm{E}-04$ & $6.6 \mathrm{E}-03$ & $1.2 \mathrm{E}-02$ & $1.2 \mathrm{E}-04$ & $5.4 \mathrm{E}-03$ & $1.3 \mathrm{E}-02$ & $1.3 \mathrm{E}-04$ & $5.6 \mathrm{E}-03$ \\
\hline Leather & $1.3 \mathrm{E}-04$ & $6.8 \mathrm{E}-04$ & 7.4E-05 & $1.9 \mathrm{E}-04$ & 9.7E-04 & $1.0 \mathrm{E}-04$ & $5.0 \mathrm{E}-04$ & $8.4 \mathrm{E}-05$ & $5.0 \mathrm{E}-04$ & 7.1E-04 & $1.2 \mathrm{E}-04$ & 7.1E-04 \\
\hline $\begin{array}{l}\text { Metalworking } \\
\text { fluids }\end{array}$ & $1.4 \mathrm{E}-06$ & $2.2 \mathrm{E}-05$ & $2.8 \mathrm{E}-07$ & $1.5 \mathrm{E}-06$ & $2.4 \mathrm{E}-05$ & $2.9 \mathrm{E}-07$ & $2.0 \mathrm{E}-06$ & $3.3 \mathrm{E}-05$ & $4.5 \mathrm{E}-06$ & $2.2 \mathrm{E}-06$ & $3.5 \mathrm{E}-05$ & 4.7E-06 \\
\hline $\begin{array}{l}\text { Polyurethane } \\
\text { foam adhesives }\end{array}$ & $2.0 \mathrm{E}-06$ & 5.9E-04 & $1.6 \mathrm{E}-04$ & $2.1 \mathrm{E}-06$ & $6.3 \mathrm{E}-04$ & $1.7 \mathrm{E}-04$ & $3.2 \mathrm{E}-06$ & $3.9 \mathrm{E}-06$ & $1.0 \mathrm{E}-04$ & $3.4 \mathrm{E}-06$ & $4.2 \mathrm{E}-06$ & 1.1E-04 \\
\hline
\end{tabular}


Figure S3. The comparison of emission estimates of SCCPs between the use of PVC and metalworking fluids into air (a) and water (b), using the emission factors from Jiang et al. ${ }^{27}$ and Zhang et al. ${ }^{28}$. The emission estimates here are the total emissions during $2018-2019$.

(a) Air

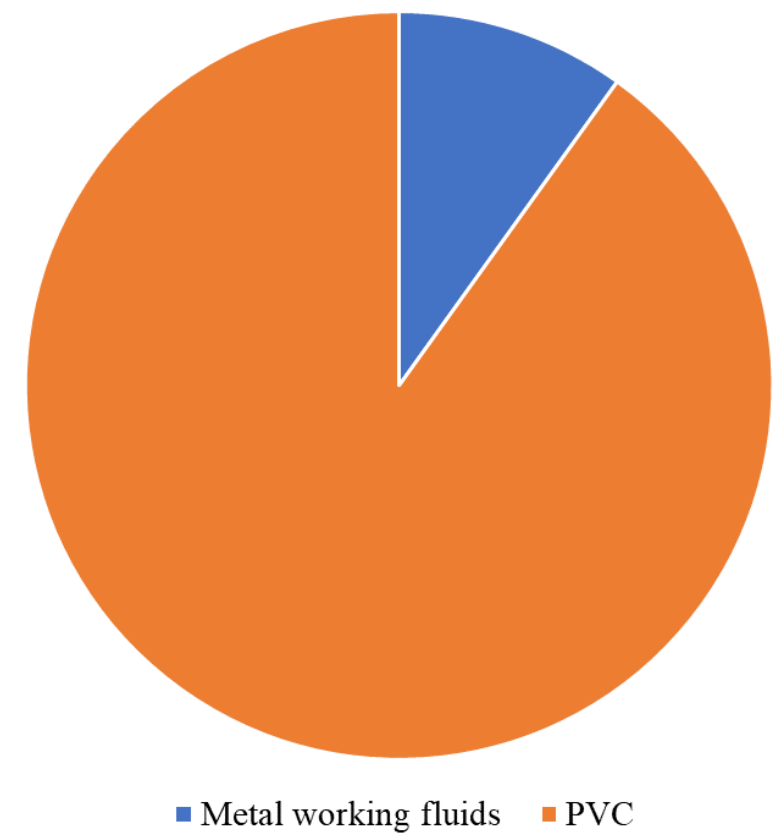

(b) Water

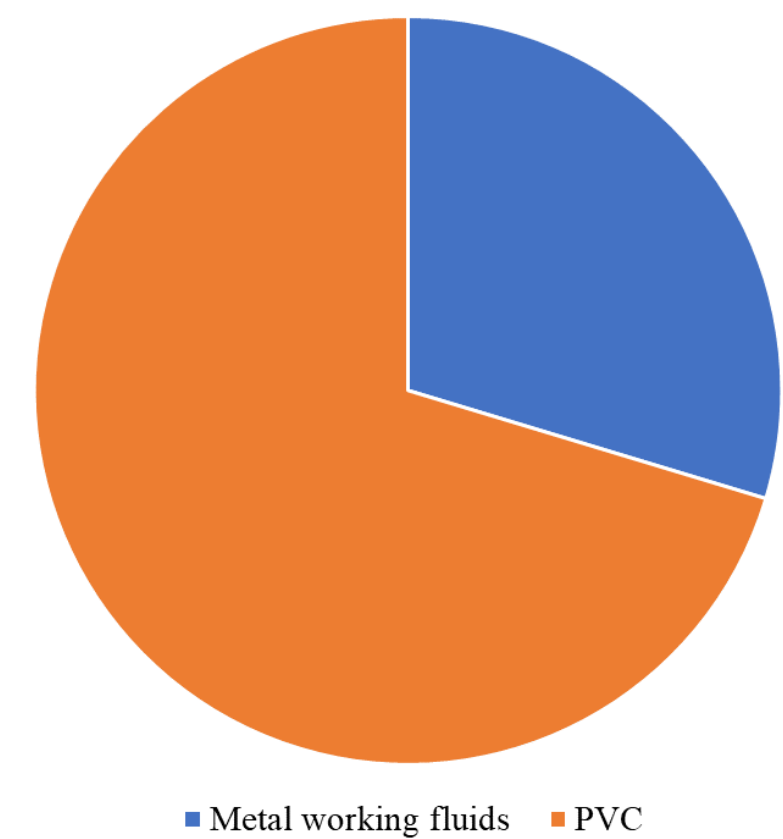


Figure S4. The upper-bound estimates for the sector distribution of SCCPs (a) and MCCPs (b) in 2018 in China.

(a) Use distribution of SCCPs in 2018

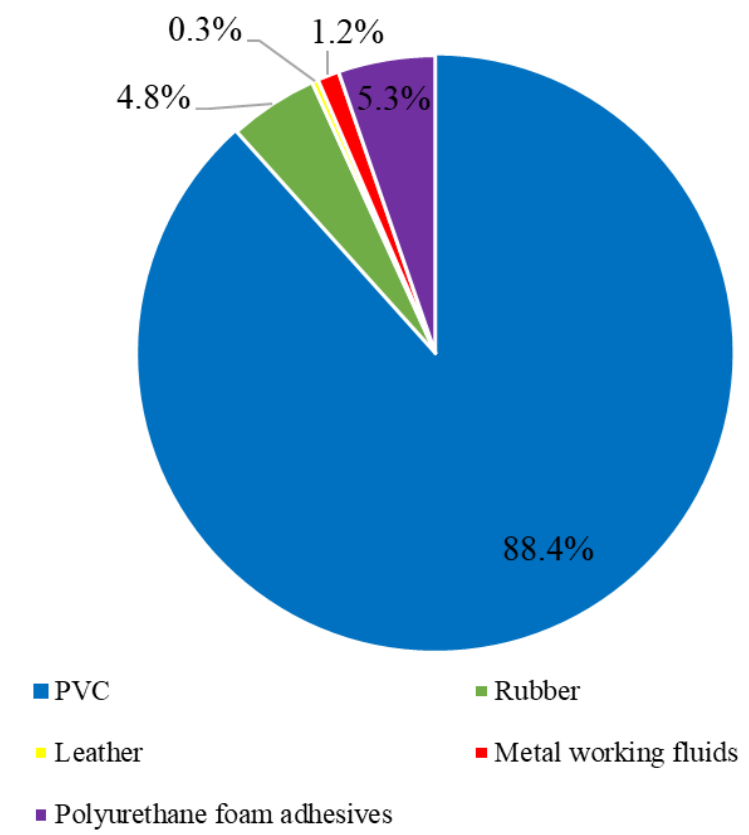

(b) Use distribution of MCCPs in 2018

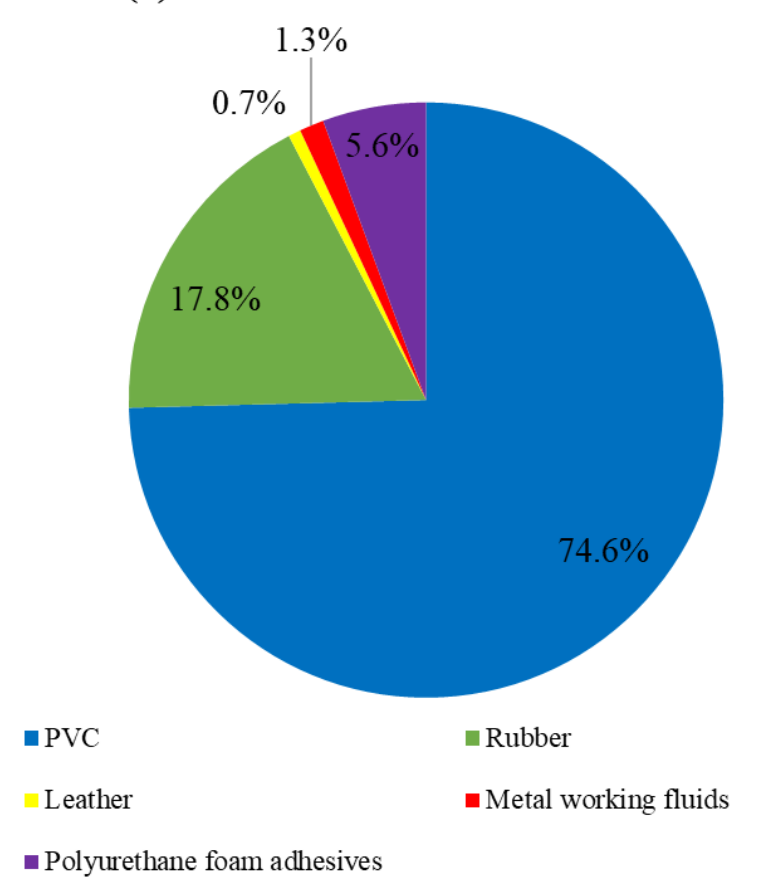


Table S18. Absolute sensitivities for production and use of SCCPs and MCCPs and six sorts of emissions to the percentage of detectable samples to total samples (noted as $f_{\mathrm{DS}}$ ), the data of production and use of eleven kinds of products, the emission factors (noted as efs) for different processes. Here the emission factors are compartment-specific, e.g., ef for production refers to ef for production into air when calculating the sensitivity of emission of SCCPs into air (0.004) to this emission factor.

\begin{tabular}{|c|c|c|c|c|c|c|c|c|c|c|}
\hline Sensitivity & $\begin{array}{l}\text { Production } \\
\text { of SCCPs }\end{array}$ & $\begin{array}{l}\text { Production } \\
\text { of MCCPs }\end{array}$ & $\begin{array}{l}\text { Use of } \\
\text { SCCPs }\end{array}$ & $\begin{array}{l}\text { Use of } \\
\text { MCCPs }\end{array}$ & $\begin{array}{l}\text { Emission o } \\
\text { of SCCPs } \\
\text { into air }\end{array}$ & $\begin{array}{c}\text { Emission } \\
\text { of SCCPs } \\
\text { into } \\
\text { surface } \\
\text { water }\end{array}$ & $\begin{array}{l}\text { Emission } \\
\text { of SCCPs } \\
\text { into soils }\end{array}$ & $\begin{array}{l}\text { Emission } \\
\text { of } \\
\text { MCCPs } \\
\text { into air }\end{array}$ & $\begin{array}{c}\text { Emission } \\
\text { of } \\
\text { MCCPs } \\
\text { into } \\
\text { surface } \\
\text { water } \\
\end{array}$ & $\begin{array}{c}\text { Emission } \\
\text { of } \\
\text { MCCPs } \\
\text { into soils }\end{array}$ \\
\hline$f_{\mathrm{D}}$ for PVC Soft plastic curtains & 0.00 & 0.01 & 0.00 & 0.00 & 0.00 & 0.00 & 0.00 & 0.00 & 0.00 & 0.00 \\
\hline$f_{\mathrm{D}}$ for PVC Hosepipe for plumbing & 0.27 & 0.28 & 0.26 & 0.25 & 0.29 & 0.07 & 0.26 & 0.24 & 0.06 & 0.26 \\
\hline$f_{\mathrm{D}}$ for PVC Electrical cable sheathing & 0.43 & 0.36 & 0.43 & 0.33 & 0.48 & 0.11 & 0.43 & 0.32 & 0.07 & 0.34 \\
\hline$f_{\mathrm{D}}$ for PVC Plastic flooring & 0.04 & 0.10 & 0.03 & 0.09 & 0.04 & 0.01 & 0.03 & 0.09 & 0.02 & 0.09 \\
\hline$f_{\mathrm{D}}$ for PVC Plastic films & 0.16 & 0.08 & 0.16 & 0.07 & 0.18 & 0.04 & 0.16 & 0.07 & 0.02 & 0.08 \\
\hline$f_{\mathrm{D}}$ for daily and medical rubber products & 0.02 & 0.09 & 0.04 & 0.17 & 0.00 & 0.01 & 0.01 & 0.21 & 0.02 & 0.04 \\
\hline$f_{\mathrm{D}}$ for coal conveyor belts & 0.01 & 0.01 & 0.01 & 0.01 & 0.00 & 0.00 & 0.00 & 0.01 & 0.00 & 0.00 \\
\hline$f_{\mathrm{D}}$ for metalworking fluids & 0.05 & 0.06 & 0.05 & 0.06 & 0.00 & 0.00 & 0.01 & 0.04 & 0.00 & 0.01 \\
\hline$f_{\mathrm{D}}$ for furniture materials & 0.01 & 0.02 & 0.01 & 0.01 & 0.00 & 0.59 & 0.00 & 0.00 & 0.70 & 0.00 \\
\hline$f_{\mathrm{D}}$ for garment materials & 0.00 & 0.01 & 0.00 & 0.01 & 0.00 & 0.07 & 0.08 & 0.01 & 0.10 & 0.16 \\
\hline$f_{\mathrm{D}}$ for polyurethane foam adhesives & 0.00 & 0.00 & 0.00 & 0.00 & 0.00 & 0.00 & 0.00 & 0.00 & 0.00 & 0.00 \\
\hline Production of PVC Soft plastic curtains & 0.00 & 0.01 & - & - & 0.00 & 0.00 & 0.00 & 0.00 & 0.00 & 0.00 \\
\hline $\begin{array}{l}\text { Production of PVC Hosepipe for } \\
\text { plumbing }\end{array}$ & 0.27 & 0.28 & - & - & 0.00 & 0.01 & 0.04 & 0.01 & 0.01 & 0.04 \\
\hline $\begin{array}{c}\text { Production of PVC Electrical cable } \\
\text { sheathing }\end{array}$ & 0.43 & 0.36 & - & - & 0.00 & 0.01 & 0.07 & 0.02 & 0.02 & 0.06 \\
\hline Production of PVC Plastic flooring & 0.04 & 0.10 & - & - & 0.00 & 0.00 & 0.01 & 0.00 & 0.00 & 0.02 \\
\hline Production of PVC Plastic films & 0.16 & 0.08 & - & - & 0.00 & 0.00 & 0.03 & 0.00 & 0.00 & 0.01 \\
\hline
\end{tabular}




\begin{tabular}{|c|c|c|c|c|c|c|c|c|c|c|}
\hline $\begin{array}{l}\text { Production of daily and medical rubber } \\
\text { products }\end{array}$ & 0.02 & 0.09 & - & - & 0.00 & 0.00 & 0.00 & 0.00 & 0.00 & 0.01 \\
\hline Production of coal conveyor belts & 0.01 & 0.01 & - & - & 0.00 & 0.00 & 0.00 & 0.00 & 0.00 & 0.00 \\
\hline Production of metalworking fluids & 0.05 & 0.06 & - & - & 0.00 & 0.00 & 0.01 & 0.00 & 0.00 & 0.01 \\
\hline Production of furniture leather materials & 0.01 & 0.02 & - & - & 0.00 & 0.00 & 0.00 & 0.00 & 0.00 & 0.00 \\
\hline Production of garment leather materials & 0.00 & 0.01 & - & - & 0.00 & 0.00 & 0.00 & 0.00 & 0.00 & 0.00 \\
\hline $\begin{array}{l}\text { Production of polyurethane foam } \\
\text { adhesives }\end{array}$ & 0.00 & 0.00 & - & - & 0.00 & 0.00 & 0.00 & 0.00 & 0.00 & 0.00 \\
\hline Use of PVC Soft plastic curtains & - & - & 0.00 & 0.00 & 0.00 & 0.00 & 0.00 & 0.00 & 0.00 & 0.00 \\
\hline Use of PVC Hosepipe for plumbing & - & - & 0.26 & 0.25 & 0.29 & 0.06 & 0.22 & 0.23 & 0.04 & 0.21 \\
\hline Use of PVC Electrical cable sheathing & - & - & 0.43 & 0.33 & 0.48 & 0.10 & 0.36 & 0.30 & 0.06 & 0.28 \\
\hline Use of PVC Plastic floorings & - & - & 0.03 & 0.09 & 0.04 & 0.01 & 0.03 & 0.08 & 0.02 & 0.08 \\
\hline Use of PVC Plastic films & - & - & 0.16 & 0.07 & 0.18 & 0.04 & 0.13 & 0.07 & 0.01 & 0.06 \\
\hline $\begin{array}{l}\text { Use of daily and medical rubber } \\
\text { products }\end{array}$ & - & - & 0.04 & 0.17 & 0.00 & 0.01 & 0.01 & 0.21 & 0.02 & 0.03 \\
\hline Use of coal conveyor belts & - & - & 0.01 & 0.01 & 0.00 & 0.00 & 0.00 & 0.01 & 0.00 & 0.00 \\
\hline Use of metalworking fluids & - & - & 0.05 & 0.06 & 0.00 & 0.00 & 0.00 & 0.03 & 0.00 & 0.00 \\
\hline Use of furniture materials & - & - & 0.01 & 0.01 & 0.00 & 0.59 & 0.00 & 0.00 & 0.70 & 0.00 \\
\hline Use of garment materials & - & - & 0.00 & 0.01 & 0.00 & 0.07 & 0.08 & 0.01 & 0.10 & 0.16 \\
\hline Use of polyurethane foam adhesives & - & - & 0.00 & 0.00 & 0.00 & 0.00 & 0.00 & 0.00 & 0.00 & 0.00 \\
\hline ef for production & - & - & - & - & 0.00 & 0.02 & 0.17 & 0.04 & 0.05 & 0.16 \\
\hline ef for PVC formulation & - & - & - & - & 0.02 & 0.02 & 0.00 & 0.17 & 0.01 & 0.00 \\
\hline ef for PVC polymer processing & - & - & - & - & 0.97 & 0.19 & 0.74 & 0.51 & 0.12 & 0.64 \\
\hline ef for PVC lifetime & - & - & - & - & 0.00 & 0.00 & 0.00 & 0.00 & 0.00 & 0.00 \\
\hline ef for rubber formulation & - & - & - & - & 0.00 & 0.00 & 0.00 & 0.02 & 0.00 & 0.00 \\
\hline ef for rubber polymer processing & - & - & - & - & 0.01 & 0.01 & 0.01 & 0.21 & 0.01 & 0.03 \\
\hline ef for rubber lifetime & - & - & - & - & 0.00 & 0.00 & 0.00 & 0.00 & 0.00 & 0.01 \\
\hline ef for sealant formulation & - & - & - & - & 0.00 & 0.00 & 0.00 & 0.03 & 0.00 & 0.00 \\
\hline ef for sealant lifetime & - & - & - & - & 0.00 & 0.10 & 0.00 & 0.00 & 0.00 & 0.00 \\
\hline
\end{tabular}




\begin{tabular}{|c|c|c|c|c|c|c|c|c|c|c|}
\hline $\begin{array}{l}\text { ef for formulation of metalworking } \\
\text { fluids }\end{array}$ & - & - & - & - & 0.00 & 0.01 & 0.00 & 0.00 & 0.01 & 0.00 \\
\hline $\begin{array}{l}\text { ef for industrial use of metalworking } \\
\text { fluids }\end{array}$ & - & - & - & - & 0.00 & 0.59 & 0.00 & 0.00 & 0.69 & 0.00 \\
\hline ef for leather formulation & - & - & - & - & 0.00 & 0.02 & 0.00 & 0.00 & 0.03 & 0.00 \\
\hline ef for leather industrial use & - & - & - & - & 0.00 & 0.05 & 0.08 & 0.01 & 0.07 & 0.16 \\
\hline
\end{tabular}


Figure S5. The frequency and probability of distribution from Monte Carlo uncertainty modeling for production and use of MCCPs and SCCPs and six sorts of emissions in 2019. The input variables were assumed as normal distribution $(\mathrm{N})$. The endpoints of the red area are $2.5 \%$ and 97.5\%. The blue lines are the average outputs of Monte Carlo simulation, and the red lines are the outputs we estimated.
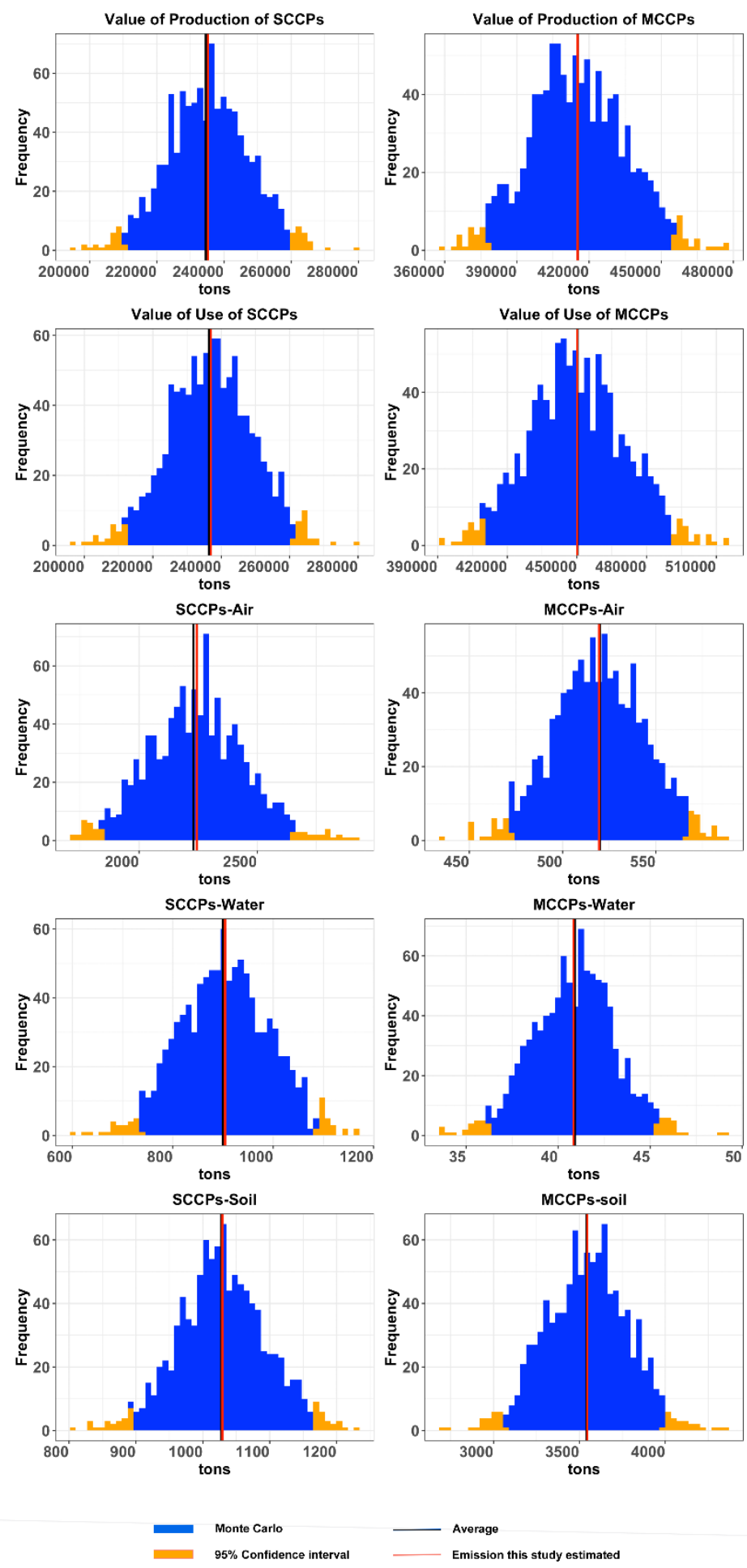


\section{Reference}

1. Reth, M.; Oehme, M., Limitations of low resolution mass spectrometry in the electron capture negative ionization mode for the analysis of short- and medium-chain chlorinated paraffins. Anal Bioanal Chem 2004, 378, (7), 1741-1747.

2. Reth, M.; Zencak, Z.; Oehme, M., New quantification procedure for the analysis of chlorinated paraffins using electron capture negative ionization mass spectrometry. J Chromatogr A 2005, 1081, (2), 225-231.

3. Wang, C.; Gao, W.; Liang, Y.; Wang, Y. W.; Jiang, G. B., Concentrations and congener profiles of chlorinated paraffins in domestic polymeric products in China. Environmental Pollution 2018, 238, 326-335.

4. Xu, L.; Wen, H.; Wen, F.; Qiu, L.; Yu, Y., Determination of short-chain chlorinated paraffins in metalworking fluids by solid phase extraction-gas chromatography (in Chinese). Guangdong Chemical Industry 2017, 44, (12), 101-102.

5. Zhang, W.; Wan, X.; Li, L.; Wang, C.; Jin, S.; Xing, J., Determination of short-chain chlorinated paraffin in leather products by solid phase extraction-gas chromatography-mass spectrometry (in Chinese). Chromatography 2014, 32, (10), 1152-1156.

6. $\quad$ Xu, C.; Gao, L. R.; Zheng, M. H.; Qiao, L.; Cui, L. L.; Wang, K. R.; Huang, D., Short- and medium-chain chlorinated paraffins in commercial rubber track products and raw materials. J Hazard Mater 2019, 380.

7. National Bureau of Statistics of China. http://www.stats.gov.cn/tjsj/ndsj/ (May 9),

8. China Plastics Processing Industry Association. http://www.cppia.com.cn/cppia1/zwhgz14/201651180601.htm (May 9),

9. National Bureau of Statistics of China. http://data.stats.gov.cn/easyquery.htm?cn=C01\&zb=A0D0M\&sj=2018 (May 9),

10. China National Light Industry Associations. http://baogao.chinabaogao.com/jixie/453502453502.html (May 9),

11. The State Development Research Center. http://data.drcnet.com.cn/dataTable?id=50\&structureId=507 (May 20),

12. Chinese Oil Industry Association. http://www.lube-info.com/magazine/ (May 20),

13. China Adhesives and Tape Industry Association. http://www.chyxx.com/industry/201907/758656.html (May 20),

14. Dalian Commodity Exchange. http://finance.sina.com.cn/money/future/20090426/11066151358.shtml (May 9), 
15. China Plastics Piping Association. http://www.chyxx.com/industry/201709/567139.html (May 9),

16. China PVC Industry Analysis Report; CITIC Securities Company Limited: 2013.

17. China Chemical Network. http://www.haqh.com/index.php?m=content\&c=index\&a=show\&catid=88\&id=4470 (May 9),

18. China Plastics Processing Industry Association. https://www.qianzhan.com/analyst/detail/220/180827-7d1b51d3.html (May 9),

19. China Chlor-Alkali Industry Association. http://free.chinabaogao.com/huagong/202006/06449B222020.html (June 9),

20. Gluge, J.; Wang, Z. Y.; Bogdal, C.; Scheringer, M.; Hungerbuhler, K., Global production, use, and emission volumes of short-chain chlorinated paraffins - A minimum scenario. Science of the Total Environment 2016, 573, 1132-1146.

21. Back, J.; Olsen, S. I.; Andersen, S. H. Chlorinated Paraffins in Denmark Dansk Toksikologi Center: 1994.

22. Enropean Chemical Bureau. European Union Risk Assessment Report: Alkanes, C14-17, chloro (MCCP) Part I - environment; ECHA: 2005.

23. KEMI Risk Reduction of Chemicals - Chlorinated Paraffins; Swedish National Chemicals Inspectorate: 1991.

24. Enropean Chemical Bureau. Technical Guidance Document on Risk Assessment - Part II; ECHA: 2003.

25. European Chemical Agency. Data on manufacture, import, export, uses and releases of alkanes, C10-13, chloro (SCCPs) as well as information on potential alternatives to its use; ECHA: 2008.

26. EPA RM2 Exit briefing on chlorinated paraffins and olefins; U.S. Environmental Protection Agency: 1993.

27. Jiang, W. Y. H.; Huang, T.; Mao, X. X.; Wang, L.; Zhao, Y.; Jia, C. H.; Wang, Y. N.; Gao, H.; Ma, J. M., Gridded emission inventory of short-chain chlorinated paraffins and its validation in China. Environmental Pollution 2017, 220, 132-141.

28. Zhang, B. Y.; Zhao, B.; Xu, C.; Zhang, J. B., Emission inventory and provincial distribution of short-chain chlorinated paraffins in China. Science of the Total Environment 2017, 581, 582-588. 